\title{
Genetic parameters and variability in physic nut accessions during early developmental stages
}

\author{
Bruno Galvêas Laviola(1), Tatiana Barbosa Rosado(1), Leonardo Lopes Bhering ${ }^{(2)}$, Adilson Kenji Kobayashi(3) \\ and Marcos Deon Vilela de Resende ${ }^{(4)}$
}

\begin{abstract}
(1)Embrapa Agroenergia, Parque Estação Biológica (PqEB) s/no, CEP 70770-901 Brasília, DF, Brazil. E-mail: bruno.laviola@embrapa.br (2)Universidade Federal de Viçosa, Avenida Peter Henry Rolfs, s/no, Campus Universitário, CEP 36570-000 Viçosa, MG, Brazil. E-mail: leonardo.bhering@ufv.br ${ }^{(3)}$ Embrapa Meio-Norte, Avenida Duque de Caxias, no 5.650, Bairro Buenos Aires, CEP 64006-220 Teresina, PI, Brazil. E-mail: Adilson@cpamn.embrapa.br ${ }^{(4)}$ Embrapa Florestas, Estrada da Ribeira, Km 111, Caixa Postal 319, CEP 83411-000 Colombo, PR, Brazil. E-mail: marcos.deon@gmail.com
\end{abstract}

\begin{abstract}
The objective of this work was to estimate the genetic parameters and variability among accessions (half-sib families) of physic nut (Jatropha curcas) during the early stages of development. For this study, 110 accessions in the first year of development of the physic nut germplasm bank, maintained at Embrapa Cerrados, DF, Brazil, were evaluated in situ. The experiment was established in a randomized complete block design, with two replicates and five plants per plot arranged in rows at $4 \times 2 \mathrm{~m}$ spacing. Grain yield, total number of branches per plant, plant height, stem diameter, canopy projection on the row, canopy projection between rows, canopy volume, number of days until first flowering and height of the first inflorescence were evaluated. Estimates of vegetative genetic parameters showed the existence of genetic variability in the physic nut germplasm bank. Physic nut accessions of the germplasm bank were grouped into five similarity groups based on character divergence. Although preliminary, the obtained results are promising for showing potential for Jatropha improvement with selective efficiency.
\end{abstract}

Index terms: Jatropha curcas, germplasm bank, plant breeding.

\section{Parâmetros genéticos e variabilidade em acessos de pinhão-manso no estágio inicial de desenvolvimento}

Resumo - O objetivo deste trabalho foi estimar os parâmetros genéticos e a variabilidade entre acessos (famílias de meios-irmãos) de pinhão-manso (Jatropha curcas) no estágio inicial de desenvolvimento. Para este estudo, foram avaliados in situ 110 acessos, no primeiro ano de desenvolvimento, do banco de germoplasma mantido na Embrapa Cerrados. O experimento foi implantado em delineamento de blocos completos ao acaso, com duas repetições e cinco plantas por parcela, dispostas em linha no espaçamento de 4x2 m. Foram avaliados os caracteres: produção de grãos, número total de ramos por planta, altura de plantas, diâmetro de caule, projeção da copa na linha, projeção da copa na entrelinha, volume da copa, numero de dias para o primeiro florescimento e altura da primeira inflorescência. As estimativas dos parâmetros genéticos de caracteres vegetativos mostraram a existência de variabilidade genética no banco de germoplasma de pinhão-manso. Os acessos do banco de germoplasma de pinhão-manso foram agrupados em cinco grupos de similaridade, com base na divergência dos caracteres avaliados. Embora preliminares, os resultados obtidos são promissores por mostrar o potencial para o melhoramento de Jatropha com eficiência seletiva.

Termos para indexação: Jatropha curcas, banco de germoplasma, melhoramento vegetal.

\section{Introduction}

Jatropha curcas L. is a perennial monoecious species belonging to the family Euphorbiaceae. The adoption of physic nut as a potential crop to meet the Programa Nacional de Produção e Uso de Biodiesel (National Program for Production and Use of Biodiesel, in Brazil) is mainly due to its high potential for grain yield and, as a nonfood species, for crop management adequate for family farming (Laviola et al., 2010).
The use of appropriate techniques for selection allows gain maximization by managing breeding programs more efficiently. Thus, the use of methodologies that increase the accuracy of the selective process is of utmost importance. In this context, an optimal procedure for predicting random variables (genetic values) is the BLUP (best linear unbiased prediction) (Henderson, 1984; Searle et al., 1992), which assumes that variance components are known. For practical purposes, variance components should be estimated as accurately

Pesq. agropec. bras., Brasília, v.45, n.10, p.1117-1123, out. 2010 
as possible, using the standard procedure by applying linear mixed models, which is the restricted maximum likelihood (REML), according to Searle et al. (1992). This procedure permits the selection of individuals with the highest breeding values, regardless of their origin. In terms of selection, this strategy is better than selecting provenances (Resende et al., 1997). However, to date, few studies on physic nut have been carried out to ascertain the estimates of genetic parameters of the crop's important characters (Ginwal et al., 2004, 2005; Abreu et al. 2009). Estimates and understanding of genetic parameters are important for the elucidation of the genetic structure of the population, for the inference on the population's genetic variability and to provide subsidies to predict the genetic gains in the breeding program. Estimates such as heritability and genetic correlations are essential for the success of plant breeding strategies.

The objective of this work was to estimate the genetic parameters and the variability in 110 accessions (half-sib families) in the early stages of development of Embrapa's physic nut germplasm bank.

\section{Materials and Methods}

The experiment was done with accessions of the physic nut germplasm bank established in the experimental area of Embrapa Cerrados in Planaltina, Distrito Federal, Brazil, at $15^{\circ} 35^{\prime} 30^{\prime \prime} \mathrm{S}$ and $47^{\circ} 42^{\prime} 30^{\prime \prime}$ $\mathrm{W}$, at 1,007-m altitude. The climate is classified as Aw, tropical with dry winter and rainy summer, according to Köppen-Geiger. The annual climatic variables are: $28.4^{\circ} \mathrm{C}$ maximum temperature, $16.4^{\circ} \mathrm{C}$ minimum and $21.6^{\circ} \mathrm{C}$ average. Relative humidity ranged from 88 to $42 \%$ with $68 \%$ average. Total rainfall for the period was $1,012.1 \mathrm{~mm}$. The soil is classified as Oxisol with high clay content.

The germplasm bank was established from seeds collected from isolated plants of $J$. curcas between December 2007 and May 2008, at different locations, and from materials found in collections and plantations in Brazil. The collection sites were photographed, georeferenced and described, as well as the aspect of the plant, on an "index card" to constitute the passport data. The accession seedlings were grown in nurseries by direct seeding in $280 \mathrm{~cm}^{3}$ polypropylene tubes filled with commercial substrate supplemented with superphosphate at $5 \mathrm{~kg} \mathrm{~m}^{-3}$.
The germplasm bank was established in the second half of November 2008 and currently consists of 210 accessions. For this study, 110 accessions were used for evaluation. The experiment was established in a randomized complet block design with two replicates and five plants per plot, arranged in rows and at $4 \times 2 \mathrm{~m}$ spacing. Crop management practices, liming, fertilizing, pest and disease control were carried out as a maintenance routine of the germplasm bank (Dias et al., 2007).

The soil of the experimental area was corrected with limestone to raise the base saturation to $60 \%$. At planting, $400 \mathrm{~g}$ per plant of superphosphate were applied to the soil. After planting, $200 \mathrm{~g}$ per plant of 20:00:20 fertilizer formulation were applied, divided into three applications at 30,60 and 90 days. The experiment was carried out without irrigation.

Phenotypic evaluation of the 110 accessions was done using a morphoagronomic descriptor list (grouped in yield components, agronomic characteristics and descriptors of particular interest) and periodically reassessed according to plant development (Laviola et al., 2010). The present work shows results from the first crop year (November 2008 to July 2009). The evaluated characters were: grain yield ( $\mathrm{Y}_{\text {grain, }} \mathrm{g}$ planta $^{-1}$ ); total number of branches per plant (TNB), counting the main stem and basal branch number at $40 \mathrm{~cm}$ from ground level; plant height (height, m); stem diameter ( $\mathrm{SD}, \mathrm{mm}$ ); canopy projection on the row $\left(\mathrm{CP}_{\text {row }}, \mathrm{m}\right)$; canopy projection between lines $\left(\mathrm{CP}_{\text {between, }}\right.$ $\mathrm{m})$; canopy volume $\left(\mathrm{VC}, \mathrm{m}^{3}\right)$; number of days to first flowering (NDF, day); and height of the first inflorescence (HFI, m).

The canopy volume was estimated by approximating the volume of a cylinder with elliptical base as:

$$
\mathrm{V}_{\text {canopy }}=\left(\pi \cdot \frac{\mathrm{D}_{1}}{2} \cdot \frac{\mathrm{D}_{2}}{2}\right) \mathrm{h},
$$

in which: $\mathrm{V}_{\text {canopy }}$, canopy volume $\left(\mathrm{m}^{3}\right) ; \pi, 3.14159 ; \mathrm{D}_{1}$, canopy diameter at larger spacing $(\mathrm{m}) ; \mathrm{D}_{2}$, canopy diameter in the smaller spacing $(\mathrm{m})$; $\mathrm{h}$, plant height (m).

Estimates of the genetic parameters were based on the mixed models of REML/BLUP type, using the Selegen-REML/BLUP software, according to Resende \& Dias (2000) and Resende (2002). The statistical model 1 (random blocks, half-sib progeny, several plants per plot) was given by $\mathrm{y}=\mathrm{Xr}+\mathrm{Za}+\mathrm{Wp}+\varepsilon$, in which: $y$ is the data vector; $r$ is the vector of the repetition effects (assuming fixed effects) coupled with 
the overall mean; a is the individual additive genetic effects vector (assumed to be random); $p$ is the portion effects vector, assumed to be random; and $\varepsilon$ is the error or residue vector (random) used. Capital letters represent the matrices of incidences of the effects. For the correlation analyses between genotypic values, model 102 was adopted, and for cluster analysis (Tocher method) based on Mahalanobis distance, model 104 was used.

Although belonging to different sampling sites, the half-sib progenies were analyzed together, as if belonging to the same population.

\section{Results and Discussion}

Variance components and estimates of genetic parameters (Table 1) showed, in general, the existence of genetic variability for the nine physic nut phenotypic characters in the early stage of development. The additive genetic variance is considered one of the most important parameters to quantify the improvement potential of the population and the merits of the selection strategy used to change the frequency of favorable alleles (Cruz \& Regazzi, 1994). Higher relative values of additive variance were found for the $Y_{\text {grains, }}$, height, NDF and HFI characters, which directly reflected in the magnitude of individual heritability values in the restricted sense $\left(\mathrm{h}_{\mathrm{a}}^{2}\right)$.

The individual heritability in the restricted sense $\left(\mathrm{h}_{\mathrm{a}}^{2}\right)$ was considered of high magnitude for the characters $\mathrm{Y}_{\text {grains }}(0.88)$, height (0.79), NDF (0.60) and HFI (0.74). Experiments with physic nut in India, carried out by Ginwal et al. (2004, 2005), showed higher heritability in comparison to this experiment for height (89\%), in plants evaluated at six months of age, and heritability of $97 \%$ for 24-month-old plants. Ginwal et al. (2004) observed an increase in heritability related to height of the same plants from one year to another. A study by Rao et al. (2008) found heritability of $88 \%$ for plant height in 34-month-old plants. The high magnitude values of $h_{a}^{2}$ were associated with higher selective accuracy, indicating the possibility of high precision in the selection. However, according to Resende et al. (2001), in studies using young perennial plants, it should be taken into consideration that the individual coefficient of heritability might be inflated by the genotypes $\mathrm{x}$ year interaction. In $\mathrm{Y}_{\text {grains }}$, specifically, the variance components and the genetic parameters $\left(\mathrm{V}_{\mathrm{a}}=453.90, \mathrm{CV}_{\mathrm{gi}}=154.74\right.$ and $\left.\mathrm{h}_{\mathrm{a}}^{2}=0.88\right)$ were inflated by the large variation in the data from the first year of assessment $\left(\mathrm{CV}_{\mathrm{e}}=71.08\right)$, and the interpretation of results must be done with caution. Therefore, genetic

Table 1. Estimates of genetic parameters and general statistics of the variables grain yield ( $\left.\mathrm{Y}_{\text {grains, }} \mathrm{g}\right)$, total number of branches (TNB), height $(\mathrm{m})$, stem diameter $(\mathrm{SD}, \mathrm{mm})$, canopy projection on the row $\left(\mathrm{CP}_{\text {row }}, \mathrm{m}\right)$, canopy projection between rows $\left(\mathrm{CP}_{\text {between }}, \mathrm{m}\right)$, canopy volume $\left(\mathrm{CV}, \mathrm{m}^{3}\right)$, number of days to flowering (NDF) and height of the first inflorescence (HFI, $\left.\mathrm{m}\right)$, in the analysis of 110 accessions of physic nut (Jatropha curcas).

\begin{tabular}{|c|c|c|c|c|c|c|c|c|c|}
\hline Parameter $^{(1)}$ & $Y_{\text {grains }}$ & TNB & Height & $\mathrm{SD}$ & $\mathrm{CP}_{\text {row }}$ & $\mathrm{CP}_{\text {between }}$ & $\mathrm{VC}$ & NDF & HFI \\
\hline $\mathrm{Va}$ & 453.90 & 0.903 & 0.013 & 13.85 & 0.006 & 0.006 & 0.032 & 154.63 & 0.013 \\
\hline Vplot & 60.11 & 0.479 & 0.003 & 7.25 & 0.010 & 0.013 & 0.053 & 53.88 & 0.002 \\
\hline $\mathrm{Ve}$ & 0.00 & 0.608 & 0.001 & 13.22 & 0.024 & 0.026 & 0.063 & 47.14 & 0.002 \\
\hline Vf & 514.01 & 1.991 & 0.017 & 34.32 & 0.041 & 0.046 & 0.150 & 255.66 & 0.017 \\
\hline $\mathrm{h}_{\mathrm{a}}^{2}$ & 0.88 & 0.45 & 0.79 & 0.40 & 0.15 & 0.13 & 0.22 & 0.60 & 0.74 \\
\hline $\mathrm{h}_{\mathrm{mp}}^{2}$ & 0.70 & 0.38 & 0.57 & 0.37 & 0.16 & 0.13 & 0.18 & 0.47 & 0.57 \\
\hline$c_{\text {plot }}^{2}$ & 0.17 & 0.24 & 0.17 & 0.21 & 0.26 & 0.30 & 0.36 & 0.21 & 0.14 \\
\hline Accuracy & 0.84 & 0.62 & 0.75 & 0.60 & 0.39 & 0.36 & 0.43 & 0.68 & 0.76 \\
\hline CVgi (\%) & 154.74 & 25.70 & 8.75 & 5.63 & 8.87 & 8.68 & 20.58 & 8.93 & 9.91 \\
\hline CVgp (\%) & 77.37 & 12.85 & 4.37 & 2.82 & 4.44 & 4.34 & 10.29 & 4.46 & 4.95 \\
\hline CVe (\%) & 71.08 & 23.20 & 5.35 & 5.24 & 14.59 & 15.84 & 30.53 & 6.68 & 6.02 \\
\hline CVr (\%) & 1.08 & 0.55 & 0.81 & 0.53 & 0.30 & 0.27 & 0.34 & 0.67 & 0.82 \\
\hline Mean & 13.77 & 3.69 & 1.35 & 66.01 & 0.88 & 0.89 & 0.87 & 139 & 1.14 \\
\hline Maximum & 180.86 & 9.00 & 1.87 & 89.49 & 1.66 & 1.97 & 2.71 & 206 & 1.58 \\
\hline Minimum & 0.00 & 1.00 & 0.72 & 22.01 & 0.40 & 0.44 & 0.17 & 100 & 0.64 \\
\hline
\end{tabular}

${ }^{(1)} \mathrm{V}_{\mathrm{a}}$, additive genetic variance; $\mathrm{V}_{\text {plot, }}$ environmental variance between plots, $\mathrm{V}_{\mathrm{e}}$, residual variance (environmental+ nonadditive); $\mathrm{V}_{\mathrm{f}}$, individual phenotypic variance; $h_{a}^{2}$, individual heritability in the restricted sense, i.e. additive effects; $h_{m p}^{2}$, mean heritability of progenies, assuming complete survival; $c_{\text {plot }}^{2}$, coefficient of determination of plot effect; $\mathrm{CV}_{\mathrm{gi}}$, individual additive genetic coefficient of variation; $\mathrm{CV}_{\mathrm{gp}}$, genotypic coefficient of variation among progenies; $\mathrm{CV}_{\mathrm{e}}$, residual coefficient of variation; $\mathrm{CV}_{\mathrm{r}}=\mathrm{CV}_{\mathrm{gp}} / \mathrm{CV}_{\mathrm{e}}$, relative coefficient of variation. 
parameters estimated for $\mathrm{Y}_{\text {grains }}$ in the first year of assessment should not be used for early selection to increase grain yield. For the other evaluated characters, the $\mathrm{h}_{\mathrm{a}}^{2}$ values were low, but $\mathrm{CP}_{\text {row }}$ and $\mathrm{CP}_{\text {between }}$ showed the lowest values, 0.15 and 0.13 , respectively, indicating a quantitative inheritance of traits and further difficulties in genetic gain with early selection. For all traits, the heritability of individual additive effects $\left(h_{a}^{2}\right)$ was higher than or equal to the progeny mean heritability $\left(\mathrm{h}_{\mathrm{mp}}^{2}\right)$, indicating that selection of individuals is more important than selection of families in the first year of growth.

The genetic coefficient of variation $\left(\mathrm{CV}_{\mathrm{gi}}\right)$ is another parameter commonly used to compare the genetic variability expressed by each character evaluated and, as noted by Resende (2002), the higher the $\mathrm{CV}_{\mathrm{gi}}$ value, the higher the odds of finding individuals that will provide gains from selection. The characters $Y_{\text {grains, }}$ $\mathrm{VC}$ and TNB showed individual additive genetic coefficients of variation $\left(\mathrm{CV}_{\mathrm{gi}}\right)$ above $20 \%$ (Table 1 ), thus showing considerable genetic variability in the first year of evaluation. For the other characters, the magnitude of the $\mathrm{CV}_{\mathrm{gi}}$ values was below $10 \%$, showing lower genetic variability of the accessions for these characters. The low variability found can be attributed to plant age during the assessment, considered insufficient to detect the differences, and to the high degree of relatedness between genotypes collected in Brazil (Rosado et al., 2010).

The occurrence of significant genetic variability among the evaluated plants is critical to advance genetic selection and depends on plants expressing the trait. In India, Ginwal et al. (2004) reported the occurrence of genetic differences for growth and oil content among ten accessions of physic nut, and Ginwal et al. (2005) reported considerable genetic variability in seed morphology, germination and seedling growth. Abreu et al. (2009) found significant genetic variability for four morphological characters in ten accessions in the state of Mato Grosso do Sul, Brazil.

The coefficient of determination of environmental effects among plots $\left(\mathrm{c}_{\text {plot }}^{2}\right)$ quantifies the variability within blocks. A high coefficient value indicates high environmental variation among plots within the block and high environmental correlation of the observations within plots (Sturion \& Resende, 2004). A reliable experiment on perennial plants shows coefficient values of $10 \%$ of all phenotypic variation within the blocks provided by environmental variation among plots (Resende, 2002). In the present work, the $\mathrm{c}_{\text {plot }}^{2}$ values were between the limits of 0.14 , for HFI, and 0.36 for VC (Table 1). According to Resende et al. (2001), in order to increase both individual heritability and the mean of progenies and decrease $\mathrm{c}_{\text {plot }}^{2}$, it is preferable to use smaller plots with more repetitions. Furthermore, the authors suggest that the reduction in the number of plants per plot is likely to increase the heritability in the individual block, since the smaller size and uniformity in the block may contribute to increased selective accuracy.

Regarding the accuracy estimates that represent the correlation between predicted genotypic value and true value of the individual, the results showed high accuracy for $\mathrm{Y}_{\text {grains, }}$ plant height and HFI, medium accuracy for TNB, SD and NDF, and low accuracy for the other characters evaluated (Table 1). According to Resende et al. (2001), the accuracy can be increased by improvements in the experimental design, adjustments in the plot sizes and number of replicates. In this experiment, the relatively low number of replicates used was due to the fact that the evaluations were done in a germplasm bank. A large number of accessions, in addition to many replicates, may undermine the feasibility of morphoagronomic characterization of all accessions of the germplasm bank. However, the results showed a need to reduce the size of the plots and to increase the number of replicates in order to improve precision in the estimation of the genetic parameters and the accuracy of selection for future trials.

Estimates of the experimental coefficient of variation $\left(\mathrm{CV}_{\mathrm{e}}\right)$ were low for most of the characters, which indicates a good accuracy in data analysis, considering the number of replicates used (Table 1). For the character $\mathrm{Y}_{\text {grains, }}$, the $\mathrm{CV}_{\mathrm{e}}$ was 71.08 - considered extremely high, which indicates a wide variation in the data. In the first year of growth, plants are in the formative stage of their vegetative structures and, consequently, many physiological and environmental factors may influence the expression of grain yield. Future studies using adult individuals (3 to 4-year-old plants) may provide more conclusive results on the estimates of the genetic parameters and genetic control on grain yield and its components.

The relative variation coefficient $\left(\mathrm{CV}_{\mathrm{r}}\right)$ ranged from 0.27 to 1.08 for the characters evaluated in young plants (Table 1). According to Vencovsky (1987), $\mathrm{CV}_{\mathrm{r}}$ values near or above 1 indicate a high 
probability of genetic gain for selection among populations, suggesting that the trait can be easily worked in breeding programs. In this sense, $\mathrm{Y}_{\text {grains, }}$ height, NDF and HFI, which showed $\mathrm{CV}_{\mathrm{r}}$ above 0.67 are sufficient to provide an accurate inference on the genotypic value of the progenies. In the present study, considering the variables with high accuracy, selection efficiency could be achieved even with $\mathrm{CV}_{\mathrm{g}} / \mathrm{CV}_{\mathrm{e}}$ lower than 1.0 (Resende \& Duarte, 2007).

Table 2 presents the estimates of genotypic correlations among the nine characters. The values of genetic correlations have been used to inform breeding programs, since they reflect the fraction of the phenotypic expression of two characters, which is co-inheritable in nature (Resende, 2002). Thus, the understanding of the genotypic correlations among physic nut characters is important for the breeding program of this species, particularly in defining the criteria for selection of characters of economic importance, as well as for the construction of selection indexes for multi-traits. In the present work, correlations of higher magnitude were observed in characters with a direct relationship, for example $\mathrm{CP}_{\text {row }}$ and $\mathrm{VC}$, with genotypic correlation of 0.925 . Correlations of medium to low intensity were observed for other characters.

In some perennial species, such as coffee, stem diameter has shown to be genetically correlated with yield and its components (Walyaro \& Van Der Vossen, 1979; Cilas et al., 1998), a fact that highlights the importance of this character. In our experiments, a genetic correlation of 0.549 between stem diameter and total number of branches was observed, which is an important component of yield in physic nut (Saturnino et al., 2005). Among the evaluated characters, the VC showed the highest genetic correlation with grain yield per plant, indicating a potential for further evaluation studies in adult plants aiming at early and indirect selection for grain yield. (Table 2)

A high positive genetic correlation ( 0.752 ) between HFI and plant height was observed (Table 2). The height of the first inflorescence showed a high heritability (0.74), which suggests that this character is potentially suitable for early and indirect selection of genotypes with short stature plants, which is interesting to facilitate harvest operation.

Another character that should be better studied in future evaluations is the TNB, one of the most interesting production components for the breeding program. Jatropha curcas produces inflorescences in the terminal buds of branches grown in the current year, and the yield is dependent on the number of branches (Laviola et al., 2010). This study showed a genetic correlation of low intensity of this trait with grain production. However, the age of the plants may have been responsible for the low relationship between the relevant characters. It is likely that, in the first year, competition for photoassimilates and nutrients occurs, as the plant is forming the canopy.

The accessions studied were grouped into five similarity or heterotic groups (Table 3). Out of the 110 accessions, 104 genotypes were grouped in group I, three in group II and one accession for each remaining group, implying low genetic diversity for characters of these families. Abreu et al. (2009) also reported that ten accessions, evaluated in the state of Mato Grosso do Sul,

Table 2. Genetic correlations among grain yield ( $\left.\mathrm{Y}_{\text {grains, }} \mathrm{g}\right)$, total number of branches (TNB), height (m), stem diameter $(\mathrm{SD}, \mathrm{mm})$, canopy projection on the line $\left(\mathrm{CP}_{\text {row }}, \mathrm{m}\right)$, canopy projection between rows $\left(\mathrm{CP}_{\text {between }}, \mathrm{m}\right)$, canopy volume $\left(\mathrm{CV}, \mathrm{m}^{3}\right)$, number of days to flowering (NDF) and height of the first inflorescence (HFI, m), in the analysis of 110 accessions of physic nut (Jatropha curcas).

\begin{tabular}{|c|c|c|c|c|c|c|c|c|c|}
\hline & $Y_{\text {grains }}$ & TNB & Height & $\mathrm{SD}$ & $\mathrm{CP}_{\text {row }}$ & $\mathrm{CP}_{\text {between }}$ & $\mathrm{VC}$ & NDF & HFI \\
\hline$\overline{Y_{\text {grains }}}$ & 1 & $0.131^{\mathrm{ns}}$ & $0.145^{\mathrm{ns}}$ & $0.158^{\mathrm{ns}}$ & $0,371 * *$ & $0.377 * *$ & $0.438 * *$ & $-0.354 * *$ & $-0.045^{\text {ns }}$ \\
\hline TNB & & 1 & $-0.276^{* *}$ & $0.549 * *$ & $0.638^{* *}$ & $0.646^{* *}$ & $0.526^{* *}$ & $-0.032^{\mathrm{ns}}$ & $-0.130^{\text {ns }}$ \\
\hline Height & & & 1 & $0.155^{\mathrm{ns}}$ & $0.095^{\mathrm{ns}}$ & $0.079^{\mathrm{ns}}$ & $0.348 * *$ & $0.015^{\mathrm{ns}}$ & $0.752 * *$ \\
\hline SD & & & & 1 & $0.658 * *$ & $0.656 * *$ & $0.667 * *$ & $0.017^{\mathrm{ns}}$ & $0.239^{*}$ \\
\hline $\mathrm{CP}_{\text {row }}$ & & & & & 1 & $0.863 * *$ & $0.925 * *$ & $-0.068^{\mathrm{ns}}$ & $0.119^{\mathrm{ns}}$ \\
\hline $\mathrm{CP}_{\text {between }}$ & & & & & & 1 & $0.916 * *$ & $-0.091^{\mathrm{ns}}$ & $0.103^{\mathrm{ns}}$ \\
\hline $\mathrm{VC}$ & & & & & & & 1 & $-0.090^{\mathrm{ns}}$ & $0.304 * *$ \\
\hline NDF & & & & & & & & 1 & $0.499 * *$ \\
\hline HFI & & & & & & & & & 1 \\
\hline
\end{tabular}

${ }^{n}$ nonsignificant, $* *$ and $*$ : Significant at 1 and $5 \%$ of probability by $t$ test, respectively; 
Brazil, were allocated in just two divergent groups, one with seven accessions and the other with three.

In Brazil, the separation of $J$. curcas groups is not related to geographical origin, as accessions from different regions may have the same genetic origin (Rosado et al., 2010). Crosses between selected individuals from the best families of different groups are desirable, in order to increase the genetic variability, as well as to explore heterosis.

The initial step in any breeding program refers to selection of populations to be worked, and this selection should be based on accession tests, which should be evaluated regarding the characters related to the product of interest, which in the case of physic nut is grain and oil yield. Although the studies on the evaluation of vegetative characters are still preliminary, they may be related to production traits, as found in other perennial plant species.

Although preliminary (first year of evaluation), the results of this study are promising regarding the existence of genetic variability in the $J$. curcas germplasm bank. Further evaluations, involving the same characters and other ones including the reproductive cycle, will enlarge the scientific knowledge on the genetic parameters and variability of the species. Moreover, the separation of accessions into heterotic groups, especially for yield components, is very important for the breeding program. By combining individuals or accessions from different groups, the heterosis for traits of agronomic and economic interest can also be explored. A strategy for this is the reciprocal recurrent selection (RRS), in which divergent populations are done separately with recombination of individuals (guided by the hybrid behaviors) and generation and evaluation of hybrids resulting from the combination among populations.

Table 3. Tocher grouping of 110 accessions of physic nut (Jatropha curcas), based on Mahalanobis distance.

\begin{tabular}{lll}
\hline Group & \multicolumn{1}{c}{ Accessions } \\
\hline I & 123456891011121314151617181920212223 \\
& 24252627282930313233343536373839404445 \\
& 46474849515253545657585960616263646566 \\
& 67686970717273747576777879808182838485 \\
& 8687888990919293949596979899100101102 \\
& 103104105106107108109110 \\
II & 424350 \\
III & 55 & \\
IV & 41 & \\
V & 7
\end{tabular}

\section{Conclusions}

1. Genetic parameter estimates of vegetative characters evaluated in 110 accessions of physic nut, during the first year of development, showed a genetic variability suitable for breeding programs, which can provide high selection efficiency.

2. The individual heritability in the restricted sense was considered of high magnitude for the characters grain yield, height, number of days to flowering, and height of the first inflorescence; and of intermediate to low magnitude for total number of branches, stem diameter, canopy volume, and canopy projection on the row and between rows.

3. The accessions from the physic nut germplasm bank were grouped into five distinct similarity groups based on divergence of the evaluated characters.

\section{Acknowledgments}

To Júlio Cesar Marana, Laíse Teixeira da Costa and Genivaldo José Fonseca, Embrapa Agroenergia staff members, for their dedication in conducting the work of crop management and morphoagronomical evaluation of accessions from the germplasm bank.

\section{References}

ABREU, F.B.; RESENDE, M.D.V. de; ANSELMO, J.L.; SATURNINO, H.M.; BRENHA, J.A.M.; FREITAS, F.B. de. Variabilidade genética entre acessos de pinhão-manso na fase juvenil. Magistra, v.21, p.36-40, 2009.

CILAS, C.; BOUHARMONT, P.; BOCCARA, M.; ESKES, A.B.; BARADAT, P. Prediction of genetic value for coffee production in Coffea arabica from a half-diallel with lines and hybrids. Euphytica, v.104, p.49-59, 1998.

CRUZ, C.D.; REGAZZI, A.J. Modelos biométricos aplicados ao melhoramento genético. 2.ed. Viçosa: UFV, 1994. 390p.

DIAS, L.A. dos S.; LEME, L.P.; LAVIOLA, B.G.; PALLINI FILHO, A.; PEREIRA, O.L.; DIAS, D.C.F.S.; CARVALHO, M.; MANFIO, C.E.; SANTOS, A.S. dos; SOUSA, L.C.A.; OLIVEIRA, T.S.; DIAS, D.C.F.S. Cultivo de pinhão-manso (Jatropha curcas L.) para produção de óleo combustível. Viçosa: L.A.S. Dias, 2007. 40p.

GINWAL, H.S.; PHARTYAL, S.S.; RAWAT, P.S.; SRIVASTAVA, R.L. Seed source variation in morphology, germination and seedling growth of Jatropha curcas Linn. in Central India. Silvae Genetica, v.53, p.76-80, 2005.

GINWAL, H.S.; RAWAT, P.S.; SRIVASTAVA, R.L. Seed source variation in growth performance and oil yield of Jatropha curcas Linn. in Central India. Silvae Genetica, v.53, p.186-192, 2004. 
HENDERSON, C.R. Applications of linear models in animal breeding. Guelph: University of Guelph, 1984. 462p.

LAVIOLA, B.G.; BHERING, L.L.; ALBRECHT, J.C.; ROSADO, L.T.B.; MARQUES, S.S.; MARANA, J.C.; RIBEIRO, J.A.A. Caracterização do banco de germoplasma de pinhão-manso: resultados do $1^{\circ}$ ano de avaliação. Brasília: Embrapa Agroenergia, 2010. 8p. (Embrapa Agroenergia. Comunicado técnico, 3).

RAO, G.R.;KORWAR, G.R.; SHANKER,A.K.; RAMAKRISHNA, Y.S. Genetic associations, variability and diversity in seed characters, growth, reproductive phenology and yield in Jatropha curcas L. accessions. Trees - structure and function, v.22, p.697-709, 2008.

RESENDE, M.D.V. de. Genética biométrica e estatística no melhoramento de plantas perenes. Brasília: Embrapa Informação Tecnológica; Colombo: Embrapa Florestas, 2002. 975p.

RESENDE, M.D.V. de; DIAS, L.A.S. Aplicação da metodologia de modelos mistos (REML/BLUP) na estimação de parâmetros genéticos e predição de valores genéticos aditivos e genotípicos em espécies frutíferas. Revista Brasileira de Fruticultura, v.22, p.44-52, 2000.

RESENDE, M.D.V. de; DUARTE, J.B. Precisão e controle de qualidade em experimentos de avaliação de cultivares. Pesquisa Agropecuária Tropical, v.37, p.182-194, 2007.

RESENDE, M.D.V. de; FURLANI-JÚNIOR, E.; MORAES, M.L.T. de; FAZUOLI, L.C. Estimativas de parâmetros genéticos e predição de valores genotípicos no melhoramento do cafeeiro pelo procedimento REML/BLUP. Bragantia, v.60, p.185-193, 2001.
RESENDE, M.D.V. de; STURION, J.A.; SIMEÃO, R.M.Estratégias para o melhoramento genético da erva-mate. In: CONGRESSO SUL-AMERICANO DA ERVA-MATE, 1.; REUNIÃO TÉCNICA DO CONE SUL SOBRE A CULTURA DA ERVA-MATE, 2., 1997, Curitiba. Anais. Colombo: Embrapa-CNPF, 1997. p.243-266. (Embrapa-CNPF. Documentos, 33).

ROSADO, T.B.; LAVIOLA, B.G.; FARIA, D.A.; PAPPAS, M.C.R.; BHERING, L.L.; QUIRINO, B.; GRATTAPAGLIA, D. Molecular markers reveal limited genetic diversity in a large germplasm collection of the biofuel crop Jatropha curcas L. in Brazil. Crop Science, v.50, p.2372-2382, 2010.

SATURNINO, H.M.; PACHECO, D.D.; KAKIDA, J.; TOMINAGA, N.; GONÇALVES, N.P. Cultura do pinhão-manso (Jatropha curcas L.). Informe Agropecuário, v.26, p.44-78, 2005.

SEARLE, S.R.; CASELlA, G.; MCCULLOCH, C.E. Variance components. New York: J. Wiley, 1992. 528p.

STURION, J.A.; RESENDE, M.D.V. de. Eficiência do delineamento experimental e capacidade de teste no melhoramento genético da erva-mate (Ilex paraguariensis St. Hil.). Boletim de Pesquisa Florestal, v.50, p.3-10, 2004.

VENCOVSKY, R. Herança quantitativa. In: PATERNIANI, E.; VIEGAS, G.P. (Ed.). Melhoramento e produção de milho no Brasil. 2.ed. Campinas: Fundação Cargill, 1987. p.137-214.

WALYARO, D.J.; VANDER VOSSEN, H.A.M. Early determination of yield potential in arabica coffee by applying index selection. Euphytica, v.28, p.465-472, 1979.

Received on July 7, 2010 and accepted on September 13, 2010 